\title{
Power, authority and government of companies in the information society
}

\author{
Poder, autoridad y gobierno en las empresas de la \\ sociedad de la información
}

\section{Poder, autoridade e governo nas empresas da sociedade da informação}

\author{
Daniel Fernando López- Jiménez, Ph.D ${ }^{1}$ \\ Universidad de Los Hemisferios (Ecuador) \\ daniell@uhemisferios.edu.ec \\ Patricio Vergara, Mg. ${ }^{2}$ \\ IDE Business School (Ecuador) \\ pvergara@ide.edu.ec
}

Fecha de recepción: 22 de enero de 2019

Fecha de recepción evaluador: 15 de febrero de 2019

Fecha de recepción corrección: 10 de marzo de 2019

\footnotetext{
${ }^{1}$ Daniel Fernando López- Jiménez: Comunicador Social y Periodista. Ph.D. Economía Aplicada. Magister en Sociedad de la Información y del Conocimiento. Master en Evaluación de Impacto Ambiental, Actualmente, Vicerrector de la Universidad de Los Hemisferios. Ha publicado 20 artículos científicos y libros en coautoría. https://orcid.org/0000-0002-9163-8004

${ }^{2}$ Patricio Vergara: Escuela de Negocios Business School - IDE / Universidad de Los Hemisferios. Profesor de la Escuela de Negocios Business School - IDE, de la Universidad de Los Hemisferios, doctorando de Gobierno y Cultura de las Organizaciones de la Universidad de Navarra, España. Executive Master of Business Administration (MBA) por el Instituto de Desarrollo Empresarial. Ingeniero Comercial por la Pontificia Universidad Católica del Ecuador - Facultad de Ciencias Administrativas y Contables. Director académico del MBA del IDE. Consultor empresarial en las áreas estratégicas de contabilidad y finanzas.
} 


\begin{abstract}
In the present article, an analysis is made about the power relations, authority and government of the five biggest TI and communications companies of the world in 2017: Apple, Microsoft, Google, Facebook, Amazon; from the philosopher-political approach of Plato, Aristotle, Weber, Foucault, Arendt, Luhman and Herrero, in order to establish possible similarities between the politic power and the economical-business power, from the critical postures of Byung-Chul Han, McLuhan, Castells and Negroponte.
\end{abstract}

Keywords: IT, politics, power, government, economics, communication sciences.

\title{
Resumen
}

En el presente artículo, se realiza un análisis sobre las relaciones de poder, la autoridad y el gobierno de las cinco compañías de TI y comunicaciones más grandes del mundo en 2017: Apple, Microsoft, Google, Facebook, Amazon; desde el enfoque filosófico-político de Platón, Aristóteles, Weber, Foucault, Arendt, Luhman y Herrero, a fin de establecer posibles similitudes entre el poder político y el poder económico-empresarial, desde las posturas críticas de Byung-Chul Han, McLuhan, Castells y Negroponte.

Palabras clave: TI, política, poder, gobierno, economía, ciencias de la comunicación.

\section{Resumo}

No presente artigo, é feita uma análise sobre as relações de poder, autoridade e governo das cinco maiores empresas de TI e comunicação do mundo em 2017: Apple, Microsoft, Google, Facebook, Amazon; da abordagem filosófica-política de Platão, Aristóteles, Weber, Foucault, Arendt, Luhman e Herrero, a fim de estabelecer possíveis semelhanças entre o poder político e o poder econômico-comercial, a partir das posturas críticas de Byung-Chul Han, McLuhan, Castells e Negroponte.

Palavras-chave: TI, política, poder, governo, economia, ciências da comunicação.

\section{Introduction}

The present analysis starts from the apocalyptic conception of Michel Foucault in which he warns that the power in our time has been reconfigured, establishing a hierarchical scale in which the political power prevailing until the $20^{\text {th }}$ century, has been displaced by the business economic power and the international financial power. The sphere of economic power has been reconfigured as well, going from the industrial predominance until the $90 \mathrm{~s}$ of the $20^{\text {th }}$ century, to the predominance of information processing -what Manuel Castells has called the Information Revolution-. In this same line, an analysis is made about the power relations, authority and government of the five 
biggest TI and communications companies of the world according to Forbes (2017): Apple, Microsoft, Google, Facebook, Amazon; from the philosopher-political approach of Plato, Aristotle, Weber, Focault, Arenth, Luhman and Herrero, in order to stablish possible similarities between the political power and the economical-business power, from the critical postures of Byung Chul, McLuhan, Castells and Negroponte.

\section{State of question}

Our time has been typified mainly like a Knowledge and Information Society, that is due to the economic model that has prevailed since the 1960 s of the past $20^{\text {th }}$ century, focused in the production and commercialization of information, through proliferation of the New Information and Communication Technologies (ICTs), that embraces the equipment production -hardware-, language programming -software-, and signal transmission -networks-. This dynamic made that currently 5 out of the 10 biggest companies in the world belong to this sector according to Forbes: Apple, Microsoft, Google, Facebook, Amazon ${ }^{3}$.

It seems that the old rankings were left behind, where industry and energy were the main sectors of the more developed economies in the world, and where companies like General Electric, Shell, Sony, Matsushita and British Petroleum Company led the first places highlighting the industrial era of our contemporary society. (Castells, 2009)

Nevertheless, beyond having changed the main axis of production that typifies our contemporary society, we could not say that in background the conditions that structure our human condition have changed (Arendt, 2009), and less in terms of power categories, authority and government (Herrero, 2015), those that seem to oscillate between radical selfishness that seeks the particular good. It's enough to take a look at the global management of the eradication of poverty, that according to the Population and Development report published by the World Bank, the world has become wealthier and healthier after the 80 s until our present day. Extreme poverty has gone from $41,91 \%$ in 1981 to $10,7 \%$ in $2013^{4}$, equivalent to 766,6 million people. However, and despite the increasing growing of the middle class in emerging countries like Brazil, India or South Africa the deep distances that have increased are evident -under the economical point of view-, between rich and poor $^{5}$ that suffer their population in this same period ${ }^{6}$. The major

\footnotetext{
${ }^{3}$ Retrieved April 23rd, 2016 in Forbes/ranking/empresas-mas-grandes-del-mundo-2016.html

${ }^{4}$ Extreme poverty as told by the World Bank is every person that lives with less than 1,90USD a day. $\begin{array}{lll}\text { Retrieved April 23rd, } & 2017 .\end{array}$ https://openknowledge.worldbank.org/bitstream/handle/10986/25078/210958ovSP.pdf?sequence=20\&is Allowed=y

${ }^{5}$ According to the World Bank poverty is "An extensive data base of polls done to homes in 89 countries in development provides important information on this issue, it allows us to draw up a demographic profile of the poorest located at the USD 1,9 poverty line. This poverty profile reveals that, the poorest people in the planet mainly, live in rural areas, are young, have little education, most work in agriculture and are part of large households with a greater number of children.

6 "Haiti and South Africa are the most unequal countries in the planet (for which data is available), with a Gini index that exceeded the 60 points in 2013. Another country in sub-saharan Africa (Rwanda) and other seven Latin American and Caribbean countries (Brasil, Chile, Colombia, Costa Rica, Honduras, Mexico
} 
economic powers of the planet suffer from this phenomenon as well, EEUU, China, Germany, Russia, Great Britain and Japan which still continue in the internal task of narrowing the gaps though their political schemes and their respective economies. In this same line, the world weighted Gini index for 2013 significantly increased registering the highest incidence in 25 years $^{7}$. World Bank, 2016) On the other hand the debt for the eradication of poverty by governments is still present.

It seems that the political and economic power exercised nowadays by national governments were the extension of the endless battle for power that humanity has experienced from the origins of its existence in which the triumph of the particular good over the common good, like an illogic interpretation of politics and economics -from it's possible theological dimensions: politics as government for the common good, and economic as equity in the distribution of resources- (Arendt, 1998). Despite knowledge and human conscience to solve problems that benefit their own good, it's evident that the results on a global scale have benefited just a few, leaving aside the natural aspiration of the great majority: work for sustenance, property for shelter, education for a living and health for the body and spirit (Weber, 2002)

Understanding economic and social inequalities means entering the concepts of power, authority and government, that from the point of view dealt here the Herrero's definition is appropriate in which power "is expressed in a non-coercive submission or obedience" (Herrero, 2015, p. 61), of some over others, authority from D'Ors like "a socially recognized personal knowledge" quoted by (Herrero, 2015m p. 61), and government from Socrates' conception of State, quoted by Plato in its dialogues of Republic about the born of the healthy State:

The State is born when the individual isn't self-sufficient but needs others. This is why he associates with others, these needs are: 1) food, 2) shelter, 3) clothing. Experts in every activity will provide for anyone else, receiving in return the products they need (p. 22).

This last statement could be said to give rise to the Government, as those in charge of governing on behalf of the State, assume the role of directing the designs of their people, with Plato's warning "The State is moderated when rulers and governed agree in who must govern; thus, the best part governs the worst" (Plato. 1988, p. 25)

The Platonic premise that those who rule the governed must be endowed with virtue, and especially honest, has been blurred, perhaps, from the very beginning of the republic and democracy in western culture, precisely because of the human condition of greed and desire. "It's not ·desire" itself, but the with greater purchasing power of profits that regulates materially, through the calculation of capital, the profitable production of goods". (Weber, 2002, p. 83). Aristotle already warned about "corruption", as the act of

and Panama) make up the group of the 10 most unequal countries on the planet, with Gini indexes that surpass the 50 points or are close to that figure. Inf. World Bank 2016.

${ }^{7}$ Ibíd. 
appropriation of public goods for a particular interest. It is then about the emancipation of having over being, like an intrinsic expression of desire. (Aristotle, 1998)

The tendency of appropriation of the good or property that awakens and exert one another, could be found in the desire that leads the discontent nature of humanity (Selles, 2009). This causality could be of instinctive origin in terms of subsistence that demands the preservation of life. However, unlike animals, human reason can establish abstract dimensions of truth and ethics about the good or the bad of human actions. The two dimensions as manifestations of intelligence and will constitute the human being's exercise of freedom. In this regard, Focault (1980) points that

we have to produce truth just as we have to produce wealth. On the other hand, we are also subject to the truth in the sense that truth makes law, elaborates the true speech that, at least in part, decides, transmits, pushes power effects. After all we are judged, condemned, classified, compelled to compete, destined to live in a certain way or to die according to real speeches that have specific power effects (p. 140).

In spite of the rationality that the human being applies to the decisions he makes about what's good for himself, for his people, organization or community, his actions aren't always described as good. It's evident that what's good for some is bad for others. It's not about us relativizing the good, it's about the disjunction between one good and another good (Aristotle, 1998). It'd be little argumentative, that freedom supposes the election between good and evil, since the natural tendencies of the human being is towards the good. We call this action "irrational", since they contradict the human nature itself. In Luhman's vision (1995) it's explained as: "The causality of power consists in neutralizing the will, not necessarily in bending the will of the inferior" (p. 18)

In our times, as Herrero (2015) points out, we couldn't reduce power to a coercive action; on the contrary, in productive companies we see today how "persuasion" has become one of the main motives of power, without any use of the violence characteristic of political governments, that regardless of their ideological tendency, have armies and police corps to control and dissuade divergence on territorial sovereignty and national laws. In this sense, power presupposes the relation of one domain over others, or as Weber (2002) points out "It must be understood that a social relation is one of struggle when the action is oriented for the purpose of imposing one's own will against the resistance of the other party or parties" (p. 31). The search for the common good becomes the idealist premise of those who govern others. However, this premise has lost its legitimacy, inasmuch as the government's political scenario has turned into a web of power relations, and in which the governed, as Chomsky (2017) points out, disapprove the administrative procedures of their government for lacking competent and moral authority to carry out the tasks entrusted to these.

When governments or rulers divert the purpose of their efforts aimed at the common good, prioritizing their particular interest, acts of corruption take place, which although punished by national legislations, continue to proliferate, establishing the sphere of impunity. This scenario is conductive to the distortion of relations between the different branches of the State: executive, legislative and judicial, conceived precisely to balance 
the public powers in the states of law. It's not an accident that the totalitarian regimes of the $20^{\text {th }}$ century and the recent of the $21^{\text {st }}$ century order their government strategies towards the concentration of all powers, (Arendt, 1998) including media, specially journalism, considered as the fourth power. In this regard Focault (1980) will say: "Power relations $<<$ serve $>>$ in effect, but not because they are $<<$ at the service $>>$ of a primordial economic interest but because they can be used in strategies" (p. 171)

With the mass media, and it's influence in public opinion, governments can not only govern through coercive power, which could derive from force and law, or as Weber (2002) points out "Power means the probability of imposing one's own will, within a social relationship, even against all resistance and whatever the basis of that probability (p. 43): In this sense, they must resort to the legitimacy granted by public opinion, whether through intellectuals, surveys or media (Chomsky, 2017).

The acceptance of governments by their governed has turned public management into a populist scenario with handouts as if it were a permanent political campaign, or as Luhman (1995) points out: "The power of the power bearer is greater if based on his power he can take more diverse types of decisions" (p. 15) I which it may seem that power is shared democratically through referendums that become a constant term of political approval, detracting even the political and authority dimension confusing and mixing them, as Focault (1980) warns

There are desire investments that shape power, and spread it, and causes power to be found both at the level of a policeman or a Prime Minister, and that there is no difference at all in the power exercised by a policeman and the power exercised by a minister (p. 85).

The dynamic politics of governments include, by their own nature, the management of State resources (Maquiavelo, 1999), giving way to the economy as we now it nowadays. The political-economic relationship would look like a foundational symbiosis of the two disciplines, from Weber's conception:

"Every rational "policy" uses economic orientation in the media and every policy can be at the service of economic purposes. It is also clear that, theoretically, not every economy demands the guarantee of the power of disposition through the coercive right of the State -although it is demanded by our modern economy in its current conditions" (2002, p. 47)

And, it's precisely the economy of resources, which could be identified as the factor that drives the desire of power of politicians, both from the Marxist point of view: the appropriation of capital means (Chomsky, 2017), or from liberalism: as the fair exercise of the economic freedom (Rawls, 1993), in both cases, it is admitted that the State in a greater or lesser extent, must be the driving force or at least the regulator of economic power relations.

Economic power arises in our days as a decisive actor of political power, as the authority of ideas aren't enough to consolidate a political project of any tendency. An economic security status is required, that legitimizes any government action. Economic 
security would mean that all governed enjoy a sense of stability that allows them to pursue their aspirations comfortably and with less uncertainty. In this regard, it could be said that as long as the economy grows and with it all the governed progress, the acceptance atmosphere could be convenient for the government, which in turn would translate into a sense of legitimacy of authority. Otherwise when things don't go well economically, governments face disapproval crisis and loss of legitimacy, as a circumstantial circle and relative to the welfare of every governed. "Power has very different forms of manifestation. The most direct and immediate is exteriorized as a denial of freedom. It enables the most powerful to impose their will through violence against the will of the ones subjected to power" In This regard Byung-Chul-Han (2014) defines:

However, power does not limit itself to breaking the resistance and forcing obedience: it does not necessarily have to take the form of coercion. The power that depends on violence does not represent the supreme power. The mere fact that a will arises and opposes the powerful, testifies the weakness of its power. Power is precisely where it's not schematized, the greater the power, the more quietly it acts. Power happens without it being noisy (p. 16)

In the case of democratic regimes, economy has a dynamic agent: private Enterprise. Focused in the production of wealth for the owners of capital -shareholders-, for workers -employment-, and for society -development-. In this ecosystem, the State appears as the regulator agent of power relations: State-Enterprise: taxes and business rules; State-Employee: taxes and labor standards; State-Society: development plans and public standards. All of the above regulated by law and justice, in the manner of a large legal association called Country, or as required by Weber (2002) "The State today is formally characterized by being a legal and administrative order, whose precepts can vary- by which the activity is targeted - "action of the association"- "from the administrative table" (p. 45). It should be noted that by a way of a tacit agreement, all actors converge in the market of goods and services, in which a commercial and legal agreement has been established for the value and the price of the things and the shares that are transferred and acquired, as an endless ocean of economic transactions, that have overflowed the logic of survival, for the logic of pleasure and that today, from multiple positions is seen as a "consumer society". In which the consumer becomes a dependent of the producer. Dependence that will start a new dual-power relation Client-Company.

Private or public companies are organizations of people that seek a common end (Weber, 2002). From its foundational perspectives, two deontological aspects appear: the first will be if the common end is within a moral framework; and the second will be, if the way in which all the involved are organized, is appropriate in terms of an adequate scheme of good governance in relation to the fair use of power and justice.

Regarding the second aspect, there are mainly three groups within the company, the first group are the investors or shareholders, these will be represented in the Board of Directors by their respective delegates who are appointed under different criteria, between these will always be different interests and management of influences of power. The second group is the general management and its management staff. These are assigned 
by their abilities, in relation with the recognized authority. In relation to its management, on one side they'll have the Board of Director's pressure and on the other side they'll have to achieve the commitment and alignment of the rest of the staff by means of an adequate use of their authority and power of command as pointed out by Foucault (1980) "Power, far from hindering power, produces it" (p. 107).

Then there is the broader group, the stakeholders -groups of interest-: clients, suppliers, competition, communities, media, governments and public opinion in general, etc. This group perhaps exercises the greatest power over the company, in that it can determine its permanence in the market, given the complexity of the economic relations and reputation of the company with each of them.

Additionally, the organizations typically have three mayor instances in their management. First, the definition of the value proposition, then the establishment of a business model able to fulfill the value proposition and finally financial results that show the implementation of the previous two. Under this approach, on one side, the shareholders, managers and employees will have some kind of influence on these instances. On the other side, in the same way, clients, competition, suppliers and others will try to intervene or exercise their power in the management of the organization.

In the second decade of the $21^{\text {st }}$ century, IT and communication companies have redefined the business economic order, rewriting the consumption habits of organizations, families and people in general (McLuhan, 1989). The following section will analyze the case of the five largest IT and communications companies in the world.

\section{Power, authority and government in the five biggest IT and communications companies in the world}

The American Apple Inc. appears in the Forbes magazine ranking as the largest in the world, with a stock market capital of more than 488 billion dollars. To size this amount, we could point out some countries that recorded in their GDP, (World Bank, 2017), the following values in dollars: Argentina 637.590,42, Belgium 492.681,28, Norway 398.831,96, Egypt 235.369,13, Colombia 309.191,38, Chile 277.075,94 and Ecuador 103.056,63. This relationship of values allows us to contextualize from the economic point of view, not only the dimensions of the size of the companies, but their possible economic power, expressed in the negotiation capacity between the organizations, in their interior, and between governments of countries and companies. 
Tabla 1. World's largest companies 2018 -Frist trimester

\begin{tabular}{|l|c|l|l|c|}
\hline $\mathbf{N}^{\mathbf{0}}$ & Company & $\begin{array}{c}\text { Cap. Burs. }- \\
\text { millions USD }\end{array}$ & Country & Sector \\
\hline 1 & Apple & 707,48 & USA & $\underline{\text { ICTs }}$ \\
\hline 2 & Alphabet & 622,23 & USA & $\underline{\text { ICTs }}$ \\
\hline 3 & Microsoft Corp & 579,25 & USA & $\underline{\text { ICTs }}$ \\
\hline 4 & Amazon & 576,75 & USA & Non-basic consumption \\
\hline 5 & Tencent Holdings & 439,08 & China & $\underline{\text { ICTs }}$ \\
\hline 6 & Facebook & 418,36 & USA & $\underline{\text { ICTs }}$ \\
\hline 7 & Berkshire Hathaway & 406,66 & USA & Finance \\
\hline 8 & Alibaba Group Holding & 388,98 & China & $\underline{\text { ICTs }}$ \\
\hline 9 & Jpmorgan Chase \& Co & 322,93 & USA & Finance \\
\hline 10 & ICBC & 298,56 & China & Finance \\
\hline
\end{tabular}

Source: Forbes 2018, first trimester-own adaption

\section{Apple and Microsoft: power and authority in the frontier of knowledge}

Steve Jobs and Steve Wozniak founded Apple in 1976 in California, USA. For his part Bill Gates and Paul Allen founded Microsoft in 1975, in New Mexico, USA. According Arthur's narration (2015), in his book History of Digital Wars, the first war between two companies was lived between Jobs and Gates, as the intuitive manifestation between two visionaries of the future consumption of the Hardware of Software market. On one side, Jobs bet his creativity on the design of exclusive equipment (hardwareApple), with free distribution of the software developed by themselves. In contrast, Gates bet to the business of software exclusivity (Windows) with protocol of universal use in all the equipment developed by IBM, Dell, Toshiba, HP, etc. Job's vision was characterized by its special power of conviction and negotiation among investors and specially in the support of knowledge that his partner Steve Wosniak gave him, who became the technological authority of the company. Jobs would produce the idea, and Wosniak, developed it. Gates absorbed the knowledge through the inductive method of dismemberment. On one side, he would dismantle the equipment produced by Apple to determine the languages and the interfaces that allowed the graphing on phosphor screens. On the other side, he bought from a third party an operating system that would give origin to the development of the operating system Windows.

Perhaps the power relation between Apple and Microsoft that further evidence the scope of their respective economic powers happened in the mid-90s, when the Department of Justice of the United States and the European Commission pressed charges of monopolism to Microsoft. In the same years, Jobs was separated from Apple by the Board of Directors, due to the ineffective production that meant his management for the board. This event could be catalogued -in accordance to the approach discussed here-, as 
a loss of executive authority and the loss of internal influence between the shareholders and the Board of Directors of Apple. After rejoining Apple in 1997 as Chief Executive Officer, and in the midst of the company's financial crisis, managed that his biggest competitor Microsoft, through his largest shareholder Bill Gates, invest 150 million dollars in bailout and investment capital for the new lines of action that were then evident with the incursion of the iPod, iPhone and iMac's.

Apple's strategy is manifested in the development of cutting-edge technological devices, in relation to the demand created in the consumer on the integration of utilities their devices have among themselves, allows to identify that their tactics of commercialization, loyalty and creation of Apple communities, are a reflection of the power of the company, as they order the consumption habits of their customers, as a linear programming of their future expenses, allowing the company to forecast their future investments, as a proof of the power that emanates from their economic security (Negroponte, 1995)

On his side, Microsoft bet on the operational dependence of computers in the world, except those designed by Apple's architecture: "Microsoft's first advertising slogan, where you want to go today? Suggests unlimited freedom and mobility on the web" (Byung-Chul-Han, 2014b, p. 11). This dependence caused its biggest shareholder Bill Gates, to become in 2011, according to Forbes magazine, the richest man in the world, with a fortune estimated in 82.6 billion dollars ${ }^{8}$. Business practices, which at the beginning of the constitution of their economic empire were catalogued as unfair competition, are contrasted today with the creation of the Bill and Melinda Gates foundation, which would become the largest foundation in terms of donations in the world and would turn Bill Gates into the biggest donor of the planet. It is obvious that Microsoft's economic power and especially Bill Gates' could express its economic power to carry out this endeavor.

\section{Google and its indexing power}

IT company Google was founded by Larry Page and Sergei Brin when they were still postgraduate students in Stanford in 1996. Their business model is centered in the integration of technological services, in all ICT areas, hardware, software and networks (internet), nowadays its commercial name is Alphabet Inc-A. Its search engine google.com has become the one with most usability in the world, with a $69,45 \%$ market share ${ }^{9}$.

Perhaps, the greatest power that the Google group contains, beyond the economic power centered in its different companies and lines -including YouTube, Android and all Google services-, is the indexation it makes about information in general.

Internet of Things consummates the society of control. They watch the things we use in our everyday life. They send information without pauses about our do's and don'ts.

\footnotetext{
${ }^{8}$ Retrieved Abril 23rd 2017. https://www.forbes.com.mx/las-10-personas-mas-ricas-del-planeta-2017/

${ }^{9}$ Conf. In http://buscadores-web.com/ranking/
} 
They contribute actively to the authentication of our life. Google Glasses promises us unlimited freedom (Byung-Chul-Han, 2014, p. 77).

This means the ordering and prioritization of information in a commercial convenience that users demand to be visible. Google has the power to order according to the commercial guideline, which information - of all available on the internet-, can be in the first places of the search.

\section{Facebook and the power of privacy}

Facebook is a social network post ICTs. It's not a new ICT itself, but the social interaction of the typical three known. Its technological expression is about a virtual encounter that expresses the relationship dynamics of society. It was founded on 2005 by Mark Zuckerberg, Eduardo Saverin, Chris Hughes and Dustin Moskovitz while conducting their studies at Harvard. Currently it has more than 1.350 million members in all countries of the world, except some countries where its services are banned like North Korea, among others. Facebook has represented a threat to the users themselves, in relation to the personal information found in every profile: "Biopower works on incitement. Reinforcement, control, monitoring, increase and organization of the things he subjects" (Byung-Chul-Han, 2014, p. 77).

In 2013 privacy of the network's information was compromised, when the interference of the National Security Agency of the United States was discovered, in the follow-up to millions of users, under the pretext of the fight against terrorism and the flag of national security (Kross, 2013). Perhaps private information is the main source of Facebook's power, in which can be identified with a high degree of precision, the tendencies and preferences of people, that consciously or unconsciously have given Facebook their private information. The scope and effects of Facebook in people have been analyzed by Brung-Chul-Han (2014), in which he highlights the violation of intimacy of people's lives. In this same line and contrary to the belief that social networks bring people closer he says: “This belief hasn't been accredited yet. Rather, digital communication erodes the community, the us. Destroys public space and sharpens the isolation of man. What prevails over digital communication isn't love for the other, but narcissism. (p. 52)

In this same line, McLuhan (1988) had predicted that television and technology in general would be the ideal engines of a globalization, in which would be useless to distinguish between the message, the individual and the community.

\section{Amazon and the power of e-commerce}

Amazon is dedicated to the e-commerce of goods and products in USA, Europe and recently some Latin American countries. It was founded in 1994, in Seattle by Jeff Bezos. The commercial logic of Amazon, through Bezos' vision was based on the interpretation of the logistic weaknesses in the physical commercial exchange of products, achieving, through internet, to redefine e-commerce, and interconnecting 
producers with costumers in the new environments of the virtual store, allowing them to trade all kinds of products: from books to high tech products. Possibly, the greatest power of Amazon, lies in the relational structures that have been built in the new e-commerce, in which the loyalty of their customers and suppliers is evident, as noted by its founder Jeff Bezos (2000).

\section{Conclusions}

The theoretical categories on power, authority and government from political science and sociology are applicable to the business organizations on the IT and communications sector. However, it is necessary to deepen into the business practices of each one of them, using empirical analysis methodologies, where the specific cases presented can be accurately demonstrated.

The strength of the five companies observed seem to lie on their economic power based on an accurate government management. It could not be said that the efficient economic result of the five companies is the product of a bad management of corporate governance, on the contrary it is rationally supposed, the effective management of the companies.

The five companies here discussed have shown, apparently, an efficient relation between power and authority, since these same are obvious examples of business technological innovation and economic power, meaning: authority and power.

The economic power this five companies represent, transcends the business sphere, to structurally constitute a new type of society, characterized by innovation and technological development, which due to its global dimension, has been called, the Information Society.

\section{Bibliography}

Arendt, H. (1998). Los orígenes del totalitarismo. Madrid: Grupo Santillana.

Arendt, H. (2009). La Condición Humana. Barcelona: Paidos.

Aristóteles. (1998). La Política. Sevilla: Biblioteca digital Universidad de Sevilla.

Arthur, C. (2015). Las guerras digitales: Apple, Google, Microsoft y la batalla por internet. Bogotá: Editorial Oceáno.

Banco-Mundial. (2016). Informe de Población y Desarrollo.

Bezos, J. P. (2000). Patent and Trademark Office. Washington: Amazon.com.

Byung-Chul-Han. (2014). En el Enjambre. Barcelona: Herder.

Byung-Chul-Han. (2014b). Psicopolítica. Barcelona: Herder. 
Castells, M. (2009). Comunicación y Poder. Madrid: Alianza.

Chomsky, N. (2017). El control de nuestras vidas. Difunde la idea https://www.inventati.org/ingobernables/textos/anarquistas/chomskycontrol.pdf.

Focault, M. (1980). Microfísica del Poder. Madrid: Edissa.

Herrero, M. (2015). Poder, gobierno, autoridad: la condición saludable de la vida política. Madrid: Centro de Estudios Políticos y Constitucionales.

Katz, C. (Junio de 1998). Technological and socio-historical determinism. Redes. Revista de estudios sociales de la ciencia, Vol. V(11), 15-37.

Kross, E. V. (2013). Facebook use predicts declines in subjective well-being in young adults. PloS one, 8(8), e69841.

Luhman, N. (1995). Poder. Barcelona: Anthropos.

Maquiavelo, N. (1999). El Principe. Elaleph.com.

McLuhan, M. (1988). El medio es el mensaje. Barcelona. Paidós

McLuhan, M. (1989). La Aldea Global. Barcelona: Gedisa.

Negroponte, N. (1995). Ser Digital. Buenos Aires: Atlantida.

Platón. (1988). La República. Madrid: Gredos S.A.

Ramonet, I. (1998). La tiranía de la comunicación. Barcelona: Temas de Debate.

Rawls, J. (1993). Political Liberalims. New York: Columbia University Press.

Selles, J. F. (2009). Antropología para inconformes. Pamplona: Eunsa.

Weber, M. (2002). Economía y Sociedad. Madrid: Fondo de Cultura Económica.

\section{Infographics}

https://www.forbes.com.mx/las-10-personas-mas-ricas-del-planeta2017/Forbes/ranking/empresas-mas-grandes-del-mundo-2018.html http://buscadores-web.com/ranking/ 
